\title{
黒板と文字の輝度対比に関する研究 \\ STUDY ON LUMINANCE CONTRAST OF CHARACTERS ON BLACKBOARD
}

\author{
金 恵 英*, 奥田紫乃**, 中根芳一*** \\ Hyeyoung KIM, Shino OKUDA and Yoshikazu NAKANE
}

The purpose of this study is to investigate the lighting condition for the qualitative lighting design of schoolroom in case of seeing blackboard as visual object.

The author tries to measure reflected light on the specimen (blackboard and chalk) surface by every $10^{\circ}$ incidental angle and incidental azimuth angle.

The luminance of reflected light was measured. But, the luminance of the characters on blackboard is irregular according to adhesion of chalk powder. Therfore, the author tries to measure the area ratio of chalk's and blackboard's part, and the contrast of visual object is obtained from this area ratio.

The author reveals the reflection characteristics of the position of the light source $(\Theta i, \Phi)$ and the luminance contrast by the area ratio.

\section{keywords: luminance contrast, characters on blackboard,lighting design of schoolroom} 輝度対比，黒板文字，教室照明設計

\section{1、まえがき}

近年、机上の印刷文字を視対象として、視対象の見え方や視作業 圜境の快適性の向上を目的とした様々な研究が行われている。小林 1) は標準視対象について、中根 ${ }^{2}$ は正対比視対象の読みやすさに 基づく照明設計法について、佐藤ら ${ }^{3)}$ は見やすさの評価指標として 明視 3 要素で決まる見やすさレベル（VEL）を提案した。伊藤ら4) 5) は視認問題を実効輝度と輝度差弁別闘値で解明した。

しかし、学校教室の照明設計においては、視対象は机上の印刷文 字だけでなく、前方の黒板に書かれた文字も視対象となる。黒板の 文字の特徴としては、従来から取り扱われてきた白背景に黒い文字 で表わした印刷物と異なり、背景輝度が文字の輝度より低い（以下 これを逆対比と呼ぶ）視対象物であるという点である。照明設計に 対する要求は作業性と快適性を満足させることで、明視の基本条件 である大きさ、背景輝度、輝度対比に基づいて検討する必要がある。 黒板の文字の明視の条件の中で、視対象の大きさについては、西田 ら 6) により実測調査に基づいて文字の大きさ・種類・出現頻度等が 明らかにされている。視対象を黒板の文字としたとき、見かけの大 きさは視作業者の位置によって固有のものとなる。そのうえで、黒 板の文字の見易さを決定する変動要因は、視対象の背景輝度及び輝 度対比ということになる。逆対比視対象の視認闘值である背景輝度

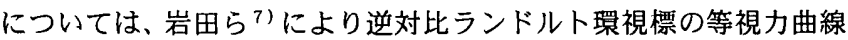

として、その視認閥値が示されている。しかし、黒板文字の輝度対 比についての実用的な資料は示されていない。一般教室のような、 灯器数・入射方向など照明条件が複数の場合での視対象物の輝度対 比を知るためには、各光源からの入射光による黒板面及び文字面で の視方向への反射光輝度を求め、それを黒板面、文字面ごとに総計 した後、辉度対比を計算するという手順を踏めばよい。このために は各種の視対象面について照度に対する視方向への反射光輝度の 比、即ち反射特性値をあらかじめ示す必要がある。そこで、本研究 は黒板を視対象にした場合の教室の照明設計法の確立を目的に、視 対象である黒板と文字の反射特性值と実際の輝度対比を求め、教室 の照明設計のための基礎資料として提示するものである。なお、本 研究は二つの実験で構成されている。黒板と文字の理想的輝度対比 は黒板と純チョークとの対比であるが、実際の教室の視対象物であ る使用黒板には色の差、污れの多少があり、チョーク線部分にはチ ヨーク粉の付着状態の差があるため、輝度対比はまちまちであり、 かつ、黒板と純チョークとの輝度対比はより小さくなる。そこで、 実験 I では、黒板の地の部分に污れと磨耗がない新しい黒板と、純 チョークでの輝度対比を測ることにした。また、実験IIでは、実際 の使用黒板とチョーク線部分の輝度対比を設定するため、新しい黒 板と純チョークの状態から害際の使用黒板とチョーク線部分の状 㑷に換算する方法と共に輝度対比を提示する。
* 大阪市立大学生活科学部生活環境学 大学院生・学修

***大阪市立大学生活科学部生活環境学 大学院生

*** 大阪市立大学生活科学部生活環境学 教授.工博
Graduate Student, Faculty of Human Life Science, Osaka City Univ., M. A. Graduate Student, Faculty of Human Life Science, Osaka City Univ. Prof., Faculty of Human Life Science, Osaka City Univ., Dr. Eng. 
2. 実験 I 黒板とチョークの試料を用いた実駧

2. 1 実験概要

1) 測定試料

本実験は、黒板の地の部分に污れと摩耗がない新しい黒板と、純 チョークでの輝度対比を測ることにした。また、黒板面とチョーク 面とに分け、各々測定試料を作成し反射光の輝度を測定した。黒板 の試料としては、一般に学校で使用されている焼付け黒板注)（パロ ン・G $\mathrm{S}-23$ ）を $150 \mathrm{~mm} \times 300 \mathrm{~mm}$ 角の大きさに切断して作成した。 チョークは、純炭酸カルシウム製（ダストレス・チョーク）の白、 黄、赤、青、緑の 5 種類の色を使用し、これを半円筒形に削って、 削り出した $65 \mathrm{~mm} \times 10 \mathrm{~mm}$ の平面部分を測定試料面とした。

\section{2 ）測定装置及び機器}

光源からの光の試料面への入射角 $\left(\Theta_{\mathrm{i}}\right)$ 、入射方位角 $(\Phi)$ 及び 反射角 $\left(\Theta_{0}\right)$ を任意に変えられる、図 1 のような装置を使用した。 光源には $650 \mathrm{~W}$ Wハロゲンランプを用いた。ランプからの光はバー の先端にあるランプにカパーをすることにより、試料面中心点に対 し視角 $2^{\circ}$ の開口部を設け、ほぼ平行光になるようにした。尚、測 定時には照度計を用いて光源の出力の変動を確かめながら測定を 行った。

測定は、天井面及び壁面に黒い布（オーカンンジー）を張り、天井・ 壁面からの反射光の測定試料面への侵入を防いだ実験室（ $2 \mathrm{~m} \times 2$ $\mathrm{m} \times 2 \mathrm{~m}$ ) で行った。

試料面輝度の測定には視角 $(1 / 3) \circ$ の輝度計（ミノルタ・ルミ ナンスメーター）を使用した。入射光照度の測定には照度計（ミノ ルタ・デジタル照度計 $\mathrm{T}-1 \mathrm{M}$ ）を使用し、試料面中央で測定を行 つた。

試料面の反射率については JIS Z 8722 に規定されている垂直／ $45^{\circ}$ で、98.9\%の輝度率を持つ標準白色板（トプコン社製W S 2）を基準に求めた。

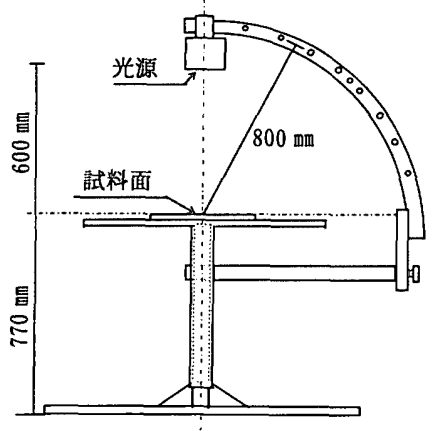

図 1 測定装置

3）測定方法

図 2 に示すように、光源の入射角 $\left(\Theta_{\mathrm{i}}\right)$ 、入射方位角 $(\Phi)$ 、反

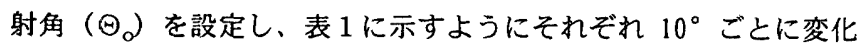
させて組み合わせ、試料面ごとに 1368 回反射光牌度を測定した。

反射角 $\left(\Theta_{0}\right)$ については、建築設計資料集成のクラスルームの平 面寸法 ${ }^{3)}$ を参考に図 3 のような一般的な教室の平面で、空から入射 する昼光により黒板面で反射グレアの起こる危険性が最も高いと
されている最前列の空の反対側の席での反射角を想定し $70^{\circ}$ を最 大とした。又、測定結果についてもこの反射グレアの起こる危険性 が最も高い反射角 $70^{\circ}$ を中心に考察を進めることにした。

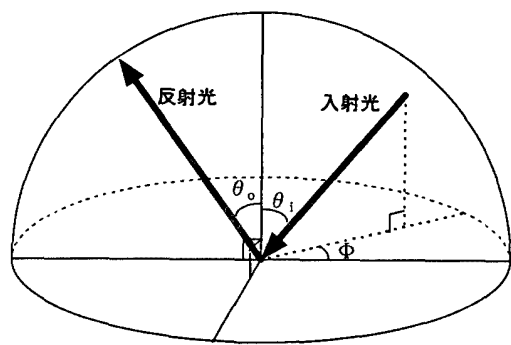

図 2 入射角 $\left(\Theta_{\mathrm{i}}\right)$ 、入射方位角 $(\Phi)$ と反射角 $\left(\Theta_{\mathrm{O}}\right)$

表 1 測定角度の組み合わせ

\begin{tabular}{|c|c|c|c|}
\hline 入射角 $\left(\Theta_{\mathrm{i}}\right)$ & \multicolumn{2}{|c|}{ 入射方位角 ( $\Phi)$} & 反射角 $\left(\Theta_{0}\right)$ \\
\hline $0^{\circ}$ & $0^{\circ}$ & $100^{\circ}$ & $0^{\circ}$ \\
\hline $10^{\circ}$ & $10^{\circ}$ & $110^{\circ}$ & $10^{\circ}$ \\
\hline $20^{\circ}$ & $20^{\circ}$ & $120^{\circ}$ & $20^{\circ}$ \\
\hline $30^{\circ}$ & $30^{\circ}$ & $130^{\circ}$ & $30^{\circ}$ \\
\hline $40^{\circ}$ & $40^{\circ}$ & $140^{\circ}$ & $40^{\circ}$ \\
\hline $50^{\circ}$ & $50^{\circ}$ & $150^{\circ}$ & $50^{\circ}$ \\
\hline $60^{\circ}$ & $60^{\circ}$ & $160^{\circ}$ & $60^{\circ}$ \\
\hline $70^{\circ}$ & $70^{\circ}$ & $170^{\circ}$ & $70^{\circ}$ \\
\hline $80^{\circ}$ & $80^{\circ}$ & $180^{\circ}$ & \\
\hline & $90^{\circ}$ & & \\
\hline
\end{tabular}

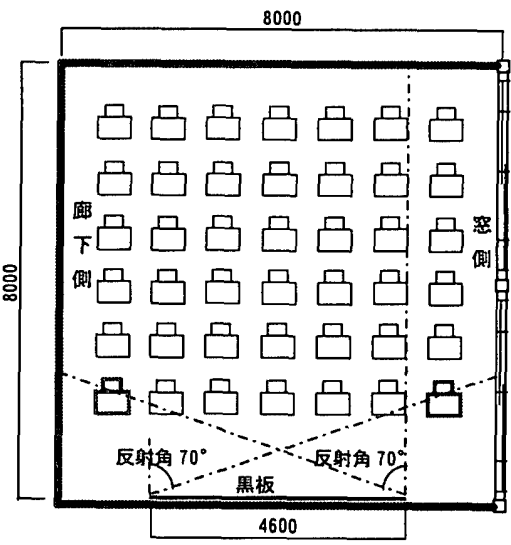

図 3 教室平面図

\section{2 試料面輝度の測定結果}

黒板面と 5 種類のチョーク面の計 6 枚の試料面について、反射光 輝度の測定を行い、得られた各輝度值を入射光水平面照度 $50001 \mathrm{x}$ のときの輝度に換算した。

各試料面に対して $45^{\circ}$ 方向から光を入射し、垂直方向の反射光を 測定した結果をそれぞれの反射率 $\left(\Theta_{\mathrm{i}}=45^{\circ} 、 \Phi=0^{\circ} 、 \Theta_{0}=0^{\circ}\right)$ とし て表 2 に示す。

入射方位角 $\Phi=0^{\circ}$ 、反射角 $\Theta_{0}=0^{\circ}$ の時の入射角 $\left(\Theta_{i}\right)$ 之輝度の 関係を求めた結果を図 4 に示す。黒板面、チョーク面ともに、入射 角が大きくなるにつれ試料面鈶直方向への反射光輝度は減少する 傾向が認められた。また、入射角 $60^{\circ}$ 位まではチョークの反射光輝 
度の低下より黒板の低下率が高くなるが、入射角 $60^{\circ}$ 以上ではチョ 一クの反射光䎌度の低下率が高くなる傾向が見られた。

5 種のチョーク共、材質が等しいことにより、入射角の変動によ る反射率の低下の傾向に著しい差異は認められず、色によって反射 率が巽なるだけであるので、以後、反射特性の詳細については白于 ヨークで代表させて測定した結果を示す。

今回の測定範囲中で鏡面反射の起こる危険性が最も高い反射角 $70^{\circ}$ のときの測定結果を図 5 に示す。これより黒板面と白チョーク 面を比較すると、黒板面では入射方位角が小さくなるにつれて反射 光輝度が上昇し、正反射の場合、反射光輝度が一番高くなる。白于 ヨーク面においても、正反射方向付近である入射角が $70^{\circ} 、 80^{\circ}$ で 鏡面反射が起きて反射光輝度の変動がみられる。しかし、白チョー ク面ではそれ以外の入射角と反射角における反射光輝度の測定結 果では入射方位角の影響をほとんど受けず值は一定で光の抎散性 が高いことが明らかである。即ち、光源の位㯰による差違が少な

表 2 各試料面の反射率

\begin{tabular}{|c|c|}
\hline 試料面 & 反射率 [\%] \\
\hline 黑板 & 6.2 \\
\hline 白チョーク & 69 \\
\hline 黄チョーク & 60.7 \\
\hline 赤チョーク & 26.8 \\
\hline 青チョーク & 24.2 \\
\hline 緑チョーク & 13.4 \\
\hline
\end{tabular}

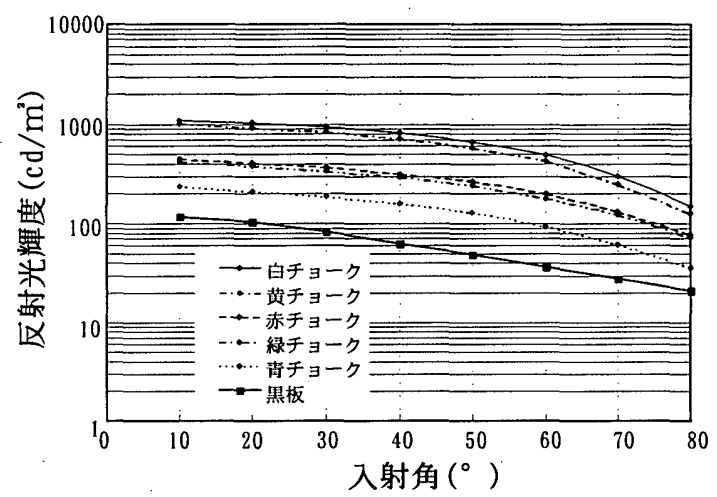

図 4 入射方位角 $0^{\circ}$ の場合の入射角と反射光輝度の関係

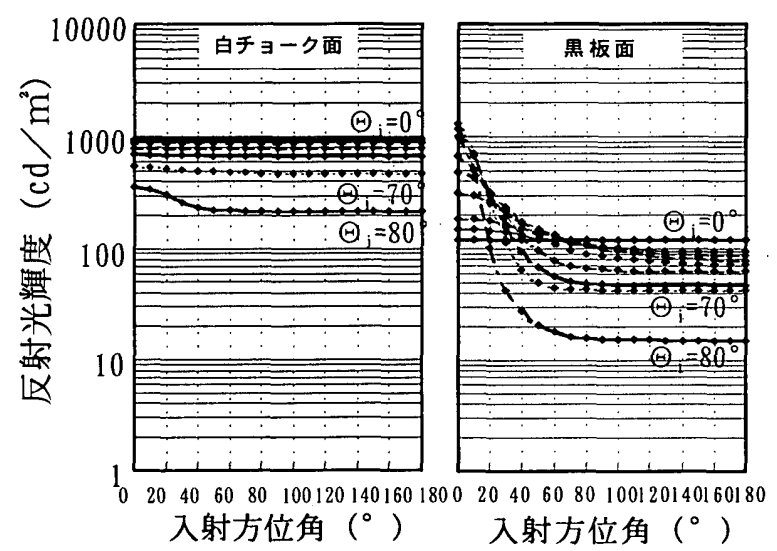

図 5 反射角 $70^{\circ}$ における光源の方位角と反射光輝度の関係
い白チョークと、チョークより表皮反射成分が強い黒板のこの両者 の反射性能の違いが、入射光の方向如何で黒板と文字との輝度対比 の減少または輝度対比を逆転させ視認性をそこなう可能性が高く なるといえる。

\section{3 黑板とチョークの反射特性値}

一般教室のような複数の照明条件の下での視対象物の輝度対比 を知るためには、各光源からの入射光による黒板面及び文字面での 視方向への反射光輝度を求めた值、即ち反射特性值をあらかじめ示 しておく必要がある。そこで、本報では反射特性値 $(\rho)$ を各種の 視対象面について単位面積当りの入射光束量に対する視方向への 反射光輝度の比で定義し、次式で表す。

$\rho\left(\Phi, \Theta_{\mathrm{i}}, \Theta_{\curvearrowright}\right)=\mathrm{L}_{\mathrm{o}} / \mathrm{E}\left[\mathrm{cd} / \mathrm{m}^{2} / \mathrm{lx}\right]$

ここに、Ф、 $\Theta_{\mathrm{i}} 、 \Theta_{\mathrm{o}}$ は入射方位角、入射角、反射角を、 $\mathrm{L}_{\mathrm{o}}$ は $\Theta_{\circ}$ 方向の試料面の輝度 $\left[\mathrm{cd} / \mathrm{m}^{2}\right]$ 、Eは試料面の照度 $[\mathrm{lx}]$ を表す。 次に、試料面測定結果から計算した黒板とチョークの反射角 $70^{\circ}$ での反射特性値を図 6 に示す。

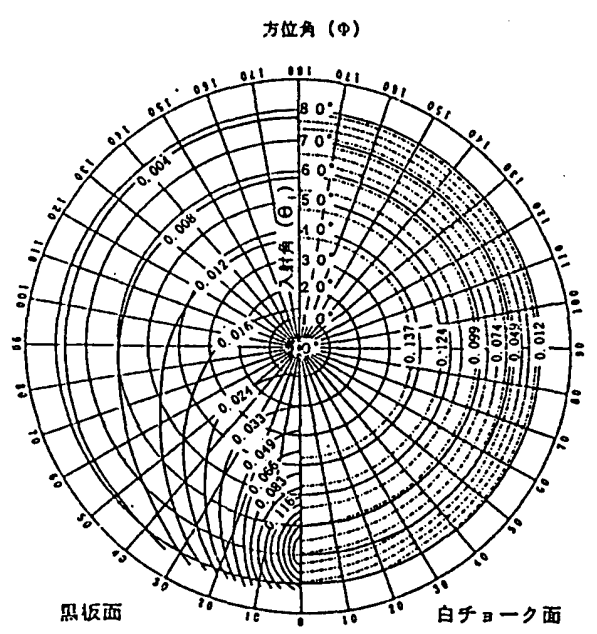

図 6 反射角 $70^{\circ}$ 場合の反射特性值

\section{4 黒板とチョークの輝度対比}

2. 3 で求めた反射特性值から黒板面及びチョーク（文字）面の 輝度対比（c）を求めた。視対象物（チョーク面）の反射特性值が

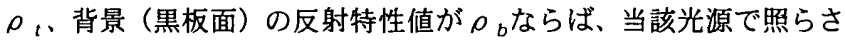
れた時の視対象の輝度対比（c）は

$\mathrm{L}_{\mathrm{t}}>\mathrm{L}_{\mathrm{b}}$ のとき $\mathrm{c}=\frac{\mathrm{L}_{\mathrm{b}}-\mathrm{L}_{\mathrm{t}}}{\mathrm{L}_{\mathrm{t}}}=\frac{\rho_{\mathrm{b}} \cdot \mathrm{E}-\rho_{\mathrm{t}} \cdot \mathrm{E}}{\rho_{\mathrm{t}} \cdot \mathrm{E}}=\frac{\rho_{\mathrm{b}}-\rho_{\mathrm{t}}}{\rho_{\mathrm{t}}}$

$\mathrm{L}_{\mathrm{b}}>\mathrm{L}_{\mathrm{t}}$, よき $\mathrm{c}=\frac{\mathrm{L}_{\mathrm{b}}-\mathrm{L}_{\mathrm{t}}}{\mathrm{L}_{\mathrm{b}}}=\frac{\rho_{\mathrm{b}} \cdot \mathrm{E}-\rho_{\mathrm{t}} \cdot \mathrm{E}}{\rho_{\mathrm{b}} \cdot \mathrm{E}}=\frac{\rho_{\mathrm{b}}-\rho_{\mathrm{t}}}{\rho_{\mathrm{b}}}$

$\mathrm{L}_{\mathrm{t}}$ : 視対象物（チョーク面）の輝度

$\mathrm{L}_{\mathrm{b}}$ : 背景 (黒板面) の輝度

$\rho_{\mathrm{t}}:$ 視対象物（チョーク面）の反射特性値

$\rho_{\mathrm{b}}:$ 背景（黒板面）の反射特性値

で求められる。

次に、黒板面及びチョーク（文字）面の輝度対比と光源位置との 関係について結果を示す。

入射方位角が $0^{\circ}$ のときの入射角、反射角と輝度対比の関係（図 7）より、反射角が $0^{\circ} \sim 30^{\circ}$ までは入射角の変化による輝度対比 
は-0.92〜-0.57で急激な変動は見られないが、反射角が $40^{\circ}$ を越 えると、入射角が大きくなるにつれて輝度対比が急激に減少する傾 向が見られる。特に入射角が $30^{\circ}$ を越えると反射角 $60^{\circ} 、 70^{\circ}$ に おいて輝度対比の変化が著しく見られ、入射角が大きくなるにつれ て輝度対比が 0 になり、以後、輝度の逆転が見られる。なお、反射 角が $40^{\circ}$ を越えると、正反射状態になると輝度対比が著しく減少す ることがわかる。

次に、反射角 $70^{\circ}$ の場合の輝度対比を図 8 より検討する。入射方 位角が $30^{\circ}$ 以上のとき、入射角の変化による辉度対比は-0.93〜0.73 で急激な変動はあまり見られない。しかし、入射方位角が $30^{\circ}$ より小さく正反射状態に近くなると輝度対比注著しく減少する。入 射方位角 $20^{\circ}$ 以下で、入射角が $30^{\circ}$ 以内のとき、輝度対比は -0.87 〜 - 0.65 の範囲で、特に視認性を損なうような輝度対比の激しい変 化は認められないといえる。しかし、入射角 $30^{\circ}$ 以上では輝度対比 の変化が激しく、特に入射方位角 $10^{\circ}$ と $0^{\circ}$ の場合、入射角が大き くなるにつれ輝度対比が減少し 0 に近付くところがあるので視認 性を損なう危険性は極めて高いといえる。また、正対比のところは 本来文字面より低い輝度である黒板面が鏡面反射を起こして、視対 象物と背景の輝度の逆転となるところで、輝度対比の低下と共に反 射グレアによってさらに見易さを損なう危険性が高くなると考え られる。

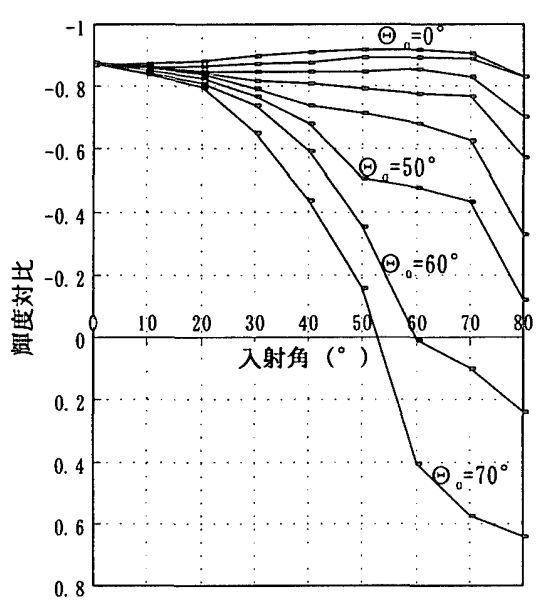

図 7 入射方位角 $0^{\circ}$ における入射角、反射角と輝度対比の関係

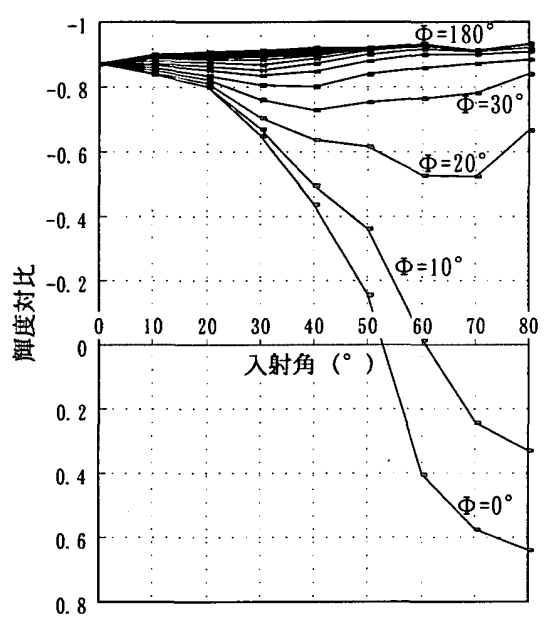

図 8 反射角 $70^{\circ}$ における光源の位置と輝度対比の関倸

\section{3. 実験 II 黒板文字の実状に基づいた実験}

\section{1 黒板文字の実状}

黒板と文字の理想的輝度対比は黒板と純チョークとの対比であ るが、実際の教室の視対象物である使用黒板には色の差、污れの多 少があり、チョークの線部分にはチョーク粉の付着状態の差がある ため、輝度対比はまちまちである。黒板の字を消した後の黒板の反 射率 $\left(\Theta_{\mathrm{i}}=45^{\circ} ， \Phi=0^{\circ} ， \Theta_{\circ}=0^{\circ}\right)$ の変化を図 9 に示した。黒板を消 す度にチョーク粉の付着量によって反射率が変化し、反射率は $10 \%$ 程度になるといえる。また、黒板に白チョークで長さ $20 \mathrm{~cm}$ の直線 20 本を書いて 60 力所の反射率 $\left(\Theta_{\mathrm{i}}=45^{\circ} 、 \Phi=0^{\circ} 、 \Theta_{0}=0^{\circ}\right)$ を測定 した結果を図 10 に示した。チョーク線部分の反射率は $38 \%$ 71\% でチョークの付着状態による変化が見られる。

そこで実験 II の黒板文字の実状に基づいた実験では、黒板と純于 ヨークの反射特性值を用い、黒板消し等によって污れた使用黒板に ついては黒板と黒板に付着したチョーク粉の面積比で輝度を求め、 チョークの線部分についてはチョークの線部分内でチョーク粉が 付着している部分と黒板の地が見えている部分との面積比で輝度 を求めて、輝度対比を設定することについて検討を行った。

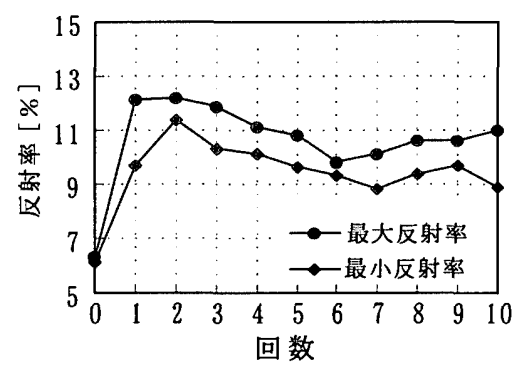

図 9 文字を消したあとの黒板の反射率

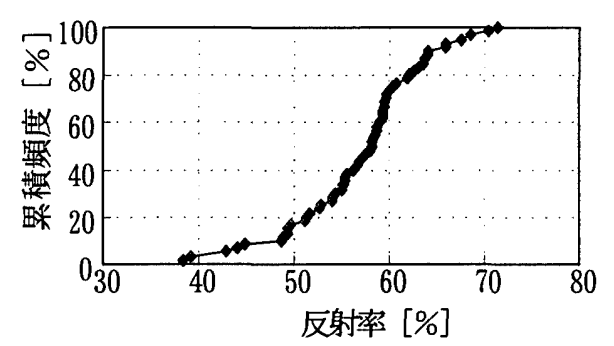

図 10 チョーク線部分の反射率の累積頻度分布

\section{2 測定概要}

3. 1 で反射率を測定した長さ $20 \mathrm{~cm} の 20$ 本のチョーク線から 1 本に 3 力所ずつ $10 \mathrm{~mm} \times 3 \mathrm{~mm}$ の面積をカラーイメージスキャナ（エプ ソン $G T-8000)$ で直接読み取り、計 60 力所の面積比を求めた。図 11 に黒板に線を書いた場合の例の一部を示した。チョーク線の面積 比 $(\mathrm{n})$ は、掠れを含むチョークの線部分の中でのチョーク粉の付 着していない部分の面積割合で求めた。

また、黒板面の污れは黒板を消した後、顕微鏡で 4 倍、10 倍の倍 率で 40 力所を昖大撮影し、スキャナで読み取り、チョーク粉が付 着している面積の割合を求めた。図 12 にチョークを消した後の黒 板表面の拡大の例の一部を示した。黒板面の面積比（m) は黒板面 
積に対しチョーク粉が付着している面積の割合で求めた。

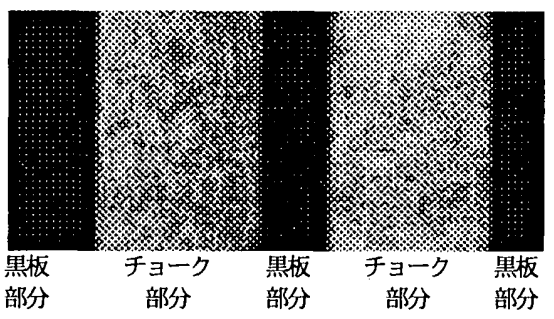

図 11 黒板に線を書いた場合の例

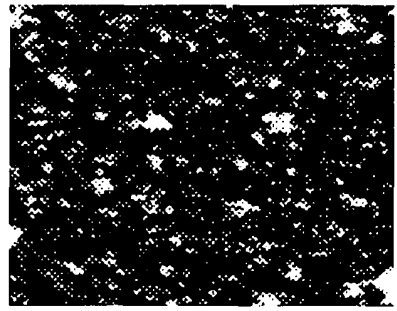

図 12 チョークを消した後の黒板表面の拡大の例

\section{3 黒板文字の輝度対比計算のための面積比測定}

掠れを含むチョークの線部分の中でのチョーク粉の付着してい ない部分の面積割合を求め図 13 に示した。また、黒板面の污れは、 黒板を消した後の黒板にチョーク粉が付着している面積の割合を 求め、図 14 に示した。

この結果を反射光輝度を算定する次式に代入すると污れた黒板 部分とチョーク線部分の輝度を求めることができる。

$\mathrm{L}_{\mathrm{t}}=\left(\rho_{\mathrm{t}} \cdot \mathrm{E}\right)(1-\mathrm{n})+\rho_{\mathrm{b}} \cdot \mathrm{E} \cdot \mathrm{n}$

$\mathrm{L}_{\mathrm{b}}=\left(\rho_{\mathrm{b}} \cdot \mathrm{E}\right) \quad(1-\mathrm{m})+\rho_{\mathrm{t}} \cdot \mathrm{E} \cdot \mathrm{m}$

また、輝度対比（c）は次のようになる。

$\mathrm{L}_{\mathrm{t}}>\mathrm{L}_{\mathrm{b}} \sigma_{\text {¿さ }} \mathrm{c}=\frac{\left(\rho_{\mathrm{b}}-\rho_{\mathrm{t}}\right)(1-\mathrm{n}-\mathrm{m})}{\rho_{\mathrm{t}}-\left(\rho_{\mathrm{t}}-\rho_{\mathrm{b}}\right) \mathrm{n}}$

$\mathrm{L}_{\mathrm{b}}>\mathrm{L}_{\mathrm{t}}$ のとき $\mathrm{c}=\frac{\left(\rho_{\mathrm{b}}-\rho_{\mathrm{t}}\right)(1-\mathrm{n}-\mathrm{m})}{\rho_{\mathrm{b}}-\left(\rho_{\mathrm{b}}-\rho_{\mathrm{t}}\right) \mathrm{m}}$

$\rho_{\mathrm{t}}$ : 視対象物（チョーク線部分）の反射特性值

$\rho_{\mathrm{b}}$ : 背景 (黒板面) の反射特性值

$\mathrm{n}$ : チョーク線の面積比（チョーク粉の付着していない面積）

チョーク線部分の面稖

$\mathrm{m}$ ：黒板面の面積比（チョーク粉が付着している面樻） 黒板面皘

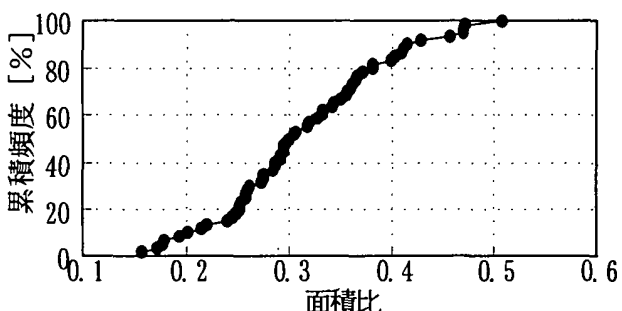

図 13 チョーク線の面積割合 $(\mathrm{n})$

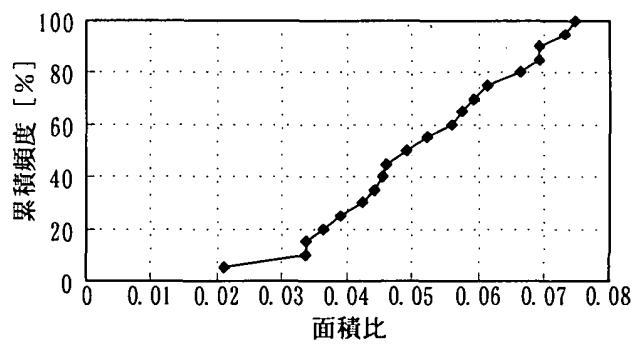

図 14 黒板面の面積割合（m）

\section{4 面皘比による黒板文字の輝度対比予測方法の検討}

面積比による黒板文字の輝度対比予測方法の検証のため、チョー ク線部分の反射率の実測值と面積比から計算で求めた值を比較し 図 15 に示した。入射角 $45^{\circ}$ 、入射方位角 $0^{\circ}$ 、反射角 $0^{\circ}$ でのチョ 一ク線部分の反射率の場合、反射率 $70 \%$ 前後の部分で計算值がやや 低くなる傾向が見られる。チョーク線部分には面積比の差やチョー ク粉の付着の厚さの差による反射光の差があると予測されるが、チ ヨーク粉の付着厚さの違いを無視して付着面積比だけを考慮して 計算した值と実測值との差は最大 $9 \%$ 、この程度の差異は視認に 著しい影響を及ぼす差ではないと考えられるので、面積比だけで輝 度対比を求めても支障ないといえる。

また、チョーク線部分の層内反射や表皮反射の差による反射光の 差について検討するため、図 3 の教室の平面図で空からの昼光によ り鏡面反射が大きい（表皮反射が多い）と予測される廊下側の一番 前の席から黒板を見た状態を想定した、入射角 $\Theta_{i}=70^{\circ}$ 、入射方位 角 $\Phi=10^{\circ}$ 、反射角 $\Theta_{0}=70^{\circ}$ の場合と、正反射が少ない（層内反射が 多い）と予測される空側の一番前の席から黒板を見た入射角 $\Theta_{i}$ $=80^{\circ}$ 、入射方位角 $\Phi=170^{\circ}$ ，反射角 $\Theta_{0}=70^{\circ}$ の場合での反射率を測 定した。反射率は、黒板に線を 10 本（反射角 $70^{\circ}$ での輝度測定面 積 $10.23 \mathrm{~mm} \times 3.5 \mathrm{~mm}$ ）書いて、標準白色板の各測定角度での辉度値を $98.9 \%$ とし求めた。反射率を測定した 10 本のチョーク線のチョー クと黒板面の面積比を求め、それと反射特性值から輝度值を計算し て求めた反射率の計算值と実測值とを比較し図 15 に示した。その 結果、入射角 $70^{\circ}$ 、入射方位角 $10^{\circ}$ 、反射角 $70^{\circ}$ でのチョーク線 の反射率は実測值より計算值の方が低くなる傾向が見られたが、視 認に著しい影響を及ぼす差はなく、その実測値と計算値の最大の差 は $7 \%$ であった。また、入射角 $80^{\circ}$ 、入射方位角 $170^{\circ}$ 、反射角 $70^{\circ}$ でのチョーク線の反射率の実測値と計算值での最大の差は $4 \%$ で あった。

上述の反射率の実測值と計算値の相関係数は $\mathrm{R}=0.966$ で、全体的 には一致しているといえる。そこで、面積比の累積頻度 $50 \%$ タイル 值と、 $90 \%$ タイル值から使用黒板とチョーク線の輝度対比を求めた。 本研究での面積比の累積頻度は\%タイル值が高くなるにつれ、チ ヨークの線部分についてはチョークの線部分内でチョーク粉が付 着してない面積が大きくなるから輝度が低くなり、また、黒板面で はチョーク粉の付着面が多くなるから輝度が高くなり、チョーク線 と使用黒板の輝度対比が低くなり、教室照明設計での設計上の安全 側になるといえる。面積比の累積頻度面積比の累積頻度 $50 \%$ 夕イル 值では 9. 7\%〜 34.5\%の対比の減少が、面積比の累積頻度 $90 \%$ タイ 
ル值では $16 \%$ 48.2\%の対比の减少が見られた。

上述の試料面の反射率と面積割合から使用黒板とチョーク線部 分の反射率を検討してみた結果、面積比の累積頻度 $50 \%$ タイル値で の使用黒板の反射率は $9.3 \%$ 、チョーク線部分の反射率は $50.2 \%$ で あった。また、面積比の累積頻度 $90 \%$ タイル值での使用黒板の反射 率は $10.5 \%$ 、チョーク線部分の反射率は $42.9 \%$ であった。

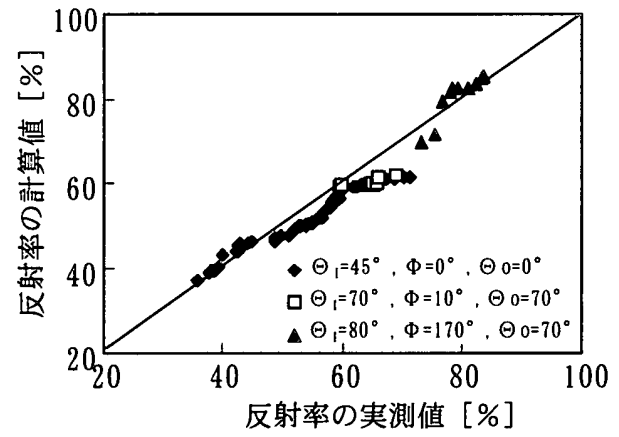

図 15 チョーク線部分の反射率の実測值と計算値比較

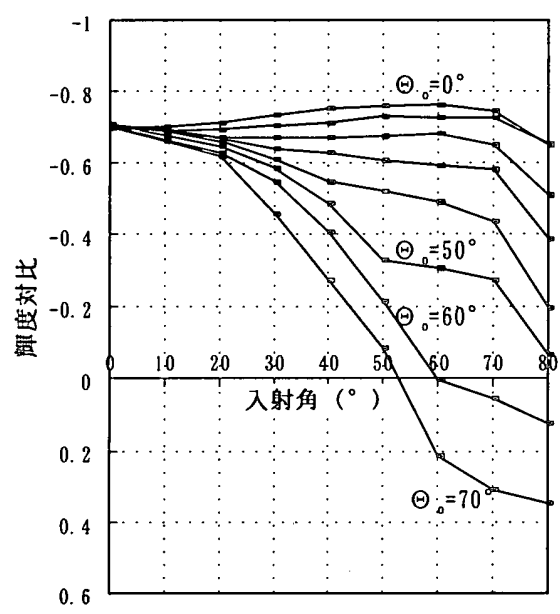

図 16 入射方位角 $0^{\circ}$ における入射角、反射角と輝度対比の関係

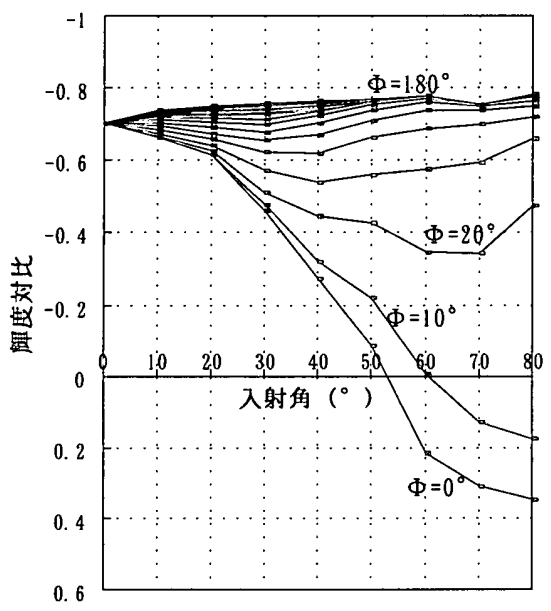

図 17 反射角 $70^{\circ}$ における光源の位置と輝度対比の関係
4. 黒板と文字（使用黒板とチョーク線）の輝度対比

教室照明設計での設計上の安全側である $90 \%$ タイル値の面積比 を用い、輝度対比を求め図 16 、図 17 に示した。使用黒板とチョー ク線の輝度対比は理想的状態である黒板とチョーク面より輝度対 比が全体的に $25.7 \%$ （対比値 0.168）低くなるが光源の位膡との関 倸は同じ傾向であった。但し、正反射方向近辺に光源がある場合の 対比の低下の現われ方は輝度対比值としては 0.01 で緩やかであっ たがパーセンテージとしては $48.2 \%$ で高くなった。これは、正反射 方向では鏡面反射によって対比が低くなっているからであるとい える。

\section{5. まとめ}

本研究では、黒板を視対象にした場合の教室の照明設計法の確立 を目的にその基礎研究として、視対象である黒板とチョークの反射 光輝度を実験により測定し輝度対比を求めた。本研究を以下にまと める。

1) 視対象である黒板と文字の輝度対比を求めるための基礎研究と して反射特性值、即ち、光源からの入射光による視方向への反射光 輝度を求めた。

2) 光の拡散性に富んだ白チョーク面と、表皮反射成分が強い黒板 との、この両者の反射性能の違いが、入射光の方向如何で輝度対比 を減少させ梘認性をそこなう原因であることがわかった。

3) 反射角 $70^{\circ}$ のとき、黒板と文字の輝度対比を求めた結果、光源 が正反射方向付近にあると対比が著しく低下し、対比の逆転で正対 比状態になることがわかった。

4) 実際の教室の使用黒板と文字の輝度対比を求めるため、それぞ れの反射特性値から、黒板は黒板に付着したチョーク粉と黒板面と の面積比で、文字部分はチョークの線部分内でチョークが付着して いる部分と黒板の地が見えている部分との面積割合で輝度対比を 設定した。その計算式を（4）式に示した。

5 ）（4）式から輝度対比を求めた結果、使用黒板とチョーク線部 分の輝度対比は黒板とチョーク面より $16 \%$ 48. $2 \%$ の減少が見ら れた。

6 ）黒板と純チョークに比べ輝度対比の低下に影響を及ぽすのは、 文字の場合のチョーク粉の付着状態の差もあるが、黒板面の場合、 チョーク粉の付着で反射率が高くなり対比の低下が大きくなると いえる。

\section{【謝辞】}

本研究を行うにあたり捉南大学工学部助教授岩田三千子・学博にご助言を頂 いた。また、データの分析においては大阪市立大学工学部教授三木信博・工博 にこ協力を頂いた。ここに記して謝意を表します。

\section{（引用文献）}

1）小林朝人：文字と文章を読む視距限について、日本建䛶学会論文報告集号 外、1966 年、 0492

2) 中根芳一: 読みやすさ評価に基づく質的照明設計法に関する研究、照明学 会誌、第 65 巻、第 10 号、1981 年、pp534-540 
3）佐藤隆二，他 2 名：見やすさに基づく明視照明設計に関する研究一照明の 評価指標としての見やすさレベル（VEL）の有効性一、照明学会誌、第 64 巻、 第10号、1980 年、pp541-548

4）伊藤克三 他 2 名: 実効料度による視認問題の統一的解明、照明学会誌、 第 72 巻、第 6 号、1988 年、pp324-331

5) 井上容子 他 2 名：視認能力に関する定量化、日本建築学会近畿支部研究 報告集、1988 年、pp101-104

6) 西田尚代 他 2 名 : 教室の照明設計のための黑板の文字の標準化に関する 研究、日本建栄学会大会学術丵演梗概集、1994 年、ppl927-1928

7) 岩田三千子 他 2 名：逆対比視標の等視力曲線に関する研究、日本建築学 会大会学術禋演梗概集、1994 年、pp1013-1014

8）建築設計資料集成 4、単位空間 II、日本建築学会編、1980 年、p45

注

注 1 ）日本工業規格の JIS S 6045 （莾付け黒板）に規定する、銅板に黒板用の

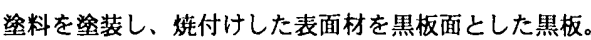

（1996年 4 月 10 日原稿受理，1997年 4 月 4 日採用決定） 